presumably to attract a wide audience. I do remember, however, that after the first lecture I heard one man say to another behind me: "What an interesting lecturer; but why did he keep referring to Atmospheric Temperature and Pressure?"

$$
\begin{aligned}
& \text { Yours faithfully, } \\
& \text { G. V. R. BoRN }
\end{aligned}
$$

Department of Pharmacology,

Royal College of Surgeons of England, Lincoln's Inn Fields,

London WC2A 3PN

\section{Ethnic Differences}

SIR,-I was pleased to read your unusually well balanced editorial (Nature,
$239,1 ; 1972)$ on the issue of the freedom of research on possible racial differences in intelligence. However, I am afraid that one important point is missing there; that is the question whether intelligence is the only criterion we should be concerned about with respect to the potential ethnic difference in mentality. There are, I think, many other aspects of possible interest and use concerning racial differences in mental activities; aggressiveness may be one, and sense for subtlety may be another. The reason why these are not on the agenda is due to the large framework-of-value system imposed on contemporary society. We have to admit that in all societies research on certain aspects of reality is being unconsciously suppressed. In order to realize this, we have to liberate ourselves from the preoccupation we are all subjected to. What would happen, for example, if it were to be demonstrated that the "quotient of aggressiveness" is significantly higher among one race (say, Caucasians) than others? The stark fact that establishing a scientific measure for aggressiveness has not been explored may simply reflect the inaccessibility to science of those who may be benefited by that type of research.

Yours faithfully, AtUHiro SibatanI 30 Owen Street, Lindfield,

\title{
Obituary
}

\section{Vsevolod P. Savich}

DR Vsevolod P. SAvich, one of the leading Russian specialists on mosses and lichens, died on May 25, 1972.

Savich was born on February 18, 1885. In 1906, while still a student at the University of St Petersburg, he began working as a laboratory assistant at the Imperial St Petersburg Botanical Gardens (now the "V. L. Komarov" Botanical Institute of the Soviet Academy of Sciences) and soon became interested in the lichens and mosses of the Arctic and sub-Arctic-an interest which, like his association with the Botanical Institute, was to last throughout his life.

Savich's main field of work was the cataloguing and mapping of the mosses and lichens of the Russian Empirelater, of the Soviet Union. He took part in a number of botanical expeditions, of which the most notable were the Kamchatka expedition of 19081910 and the 1930 expedition aboard the icebreaker G. Sedov to Franz Josef Land, Severnaya Zemlya and Vize Island. His collections during the latter expedition extended the known range for Franz Josef Land from forty-three varieties of moss and two hepaticae to eighty-three mosses and seven hepaticae. The data from these expeditions formed the basis of his later taxonomic works.

In 1932, Savich founded the Department of Lower Plants of the Botanical Institute, and became the first head of this department-a post which he was to hold for 30 years. Under his direction, the department soon became the leading body for research into these plants in the whole of the Soviet Union. Under his initiative and general editorship, the Institute published a special series of monographs and other fundamental works devoted to mosses, lichens and fungi. He was also associated with a number of more general journals, including Sovetskaya Botanika, founded in 1933, of which he and V. A. Keller were the first co-editors, and the semi-popular Priroda of which he was editor-in-chief from 1936 to 1951 , a post which he relinquished only when the headquarters of the journal were moved from Leningrad to Moscow.

In addition to his editorial work, $\mathrm{Dr}$
Savich was particularly interested in research into possible medical and other uses of lichens. In particular, he studied the application of lichen resinoids in perfumery and the possibility of obtaining antibiotics and other pharmaceuticals from lichens. The latter line of research led to the discovery of 'Binan' (sodium usninate), which for many years now has been used in surgery and gynaecology in the Soviet Union. With L. V. Lazarov, Savich edited, in 1957, a collection of studies on Binan, to which he, himself, contributed a paper "Lichens, their use in medicine and the obtaining of the new antibiotic Binan".

Dr Savich took an active part in the organization of botanical research throughout the Soviet Union. During the 1930 s he played a leading part in the organization into a single, unified Botanical Institute of the independent Botanical Gardens and Botanical Museum in Leningrad. $\mathrm{He}$ was active as an organizer and editor until his death, working until the end on the current edition of the Novosti sistematiki nizshikh rastenii.

\section{Announcements}

\section{International Meetings}

October 16, Resistance in Arthropods, London (Assistant Secretary, Society of Chemical Industry, 14 Belgrave Square, London SW1X 8PS).

October 19, Non-prescription Antibiotics in Animal Foodstuffs: their Nature and Analysis, London (F. W. Webb, Central Analytical Laboratories (Biological), The Wellcome Foundation Limited, Acacia Hall, Dartford, Kent).
October 20, Training of Food Analysts, Glasgow (Society for Analytical Chemistry, 9-10 Savile Row, London W1X 1AF).

October 25, Physics of Display Devices, London (Meetings Officer, Institute of Physics, 47 Belgrave Square, London SW1X 8QX).

October 27, Geophysical-Statistical Symposium, London (J. M. Craddock, Meteorological Office, London Road, Bracknell, Berkshire RG12 2SZ).

November 2, E. M. Holmes Anniversary Meeting, London (R. E. Marshall, Department of Pharmaceutical Sciences,
Pharmaceutical Society of Great Britain, 17 Bloomsbury Square, London WC1).

November 2, Polymers as Catalysts (Professor Moore Memorial Lecture), Bradford (The Registrar, University of Bradford, Bradford, Yorkshire BD7 1DP).

November 2-4, Neoplasia of Head and Neck, Houston (Mrs Jane Brandenberger, Information Coordinator, University of Texas, M.D. Anderson Hospital and Tumor Institute, Texas Medical Center, Houston, Texas 77025, USA).

November 5-16, Canine Immunogenetics, 